\title{
UPAYA PENINGKATAN AKTIVITAS DAN PRESTASI BELAJAR PENDIDIKAN AGAMA HINDU MELALUI PENDEKATAN SAINTIFIK TIPE GROUP INVESTIGATION (GI)
}

\author{
I Nyoman Sirtha
}

\author{
SMA Negeri 1 Mendoyo \\ e-mail: sirtha88iny@gmail.com
}

\begin{abstract}
Abstrak
Penelitian ini bertujuan untuk mendeskripsikan tentang Pendekatan saintifik tipe Group Investigation (Gl) dalam pembelajaran Pendidikan Agama Hindu di kelas XI IPS.2 SMA Negeri 1 Mendoyo Tahun Pelajaran 2018/2019. Subjek penelitian ini adalah siswa kelas XI IPS.2 Semester 1 SMA Negeri 1 tahun pelajaran 2018/2019 dengan jumlah 34 orang siswa, dimana terdiri dari 21 orang laki-laki dan 13 orang perempuan. Data yang diamati dalam penelitian ini adalah aktivitas belajar dengan menggunakan lembar observasi dan prestasi belajar siswa diamati dengan menggunakan tes sebagai cerminan hasil belajar siswa. Setelah data terkumpul akan dianalisis dengan menggunakan metode statistik deskriptif yaitu dengan menghitung rerata dan prosentase ketuntasannya dengan mengacu pada indikator keberhasilan. Penelitian ini dilaksanakan dalam 2 siklus, dimana setiap siklus dilaksanakan dengan 4 tahap, yaitu: 1). Perencanaan Tindakan, 2). Pelaksanaan Tindakan, 3), Pengamatan/Observasi, dan 4). Refleksi. Hasil penelitian dan obeservasi, serta analisis data maka dapat dikemukakan bahwa: 1).Melalui Pendekatan Saintifik Tipe Group Investigation (GI) dalam pembelajaran Pendidikan Agama Hindu siswa kelas XI IPS.2 Semester 1 SMA Negeri 1 Mendoyo ternyata dapat meningkatkan aktivitas dan prestasi belajar siswa, 2).Peningkatan aktivitas dapat terlihat dari nilai rata-rata pra siklus sebesar $56,3 \%$, di siklus I sebesar $78,5 \%$ dan siklus II sebesar $96,8 \%$. Sedangkan peningkatan aktivitas kinerja kelompok pra siklus ke siklus I meningkat rata-rata $15,56 \%$ dan siklus I ke siklus II meningkat $20,20 \%$ dengan rata-rata pada siklus II kinerja kelompok sudah dikatakan baik karena mencapai rata-rata 89,25, dan 3). Analisis prestasi belajar yang dicerminkan dari hasil belajar siswa diperoleh melalui hasil evaluasi setelah dilaksanakan tindakan yang dilakukan setiap siklus. Peningkatan prestasi belajar siswa terlihat dari jumlah siswa yang tuntas belajar pada pra siklus $64,71 \%$, siklus I sebesar $76,47 \%$, dan siklus II siswa yang tuntas mencapai $96,06 \%$. Jadi berdasarkan analisis hasil tersebut diatas, maka dapat disimpulkan bahwa: Upaya peningkatan aktivitas dan Prestasi belajar siswa, ternyata dapat ditingkatkan melalui pendekatan saintifik tipe GI dalam pembelajaran Pendidikan Agama Hindu secara signifikan.
\end{abstract}

Kata kunci: Pendekatan Saintifik, Tipe Gl, Aktivitas dan Prestasi belajar.

\begin{abstract}
This study aimed to describe the scientific approach of the Group Investigation (GI) in learning Hindu at XI IPS.2 SMA Negeri 1 Mendoyo in 2018/2019 academic year. The subjects of this study were students of XI IPS.2 Semester 1 SMA Negeri 1 Mendoyo in 2018/2019 academic year with a total of 34 students, which consisted of 21 men and 13 women. The data observed in this study were learning activities using observation sheets and student learning achievements were observed using tests as a reflection of student learning outcomes. After the data collected, it will be analyzed using descriptive statistical methods, namely by calculating the average and the percentage of completeness with reference to indicators of success. This research was conducted in 2 cycles, where each cycle was carried out with 4 stages: 1). Planning, 2). Implementation, 3) Observation, and 4). Reflection. The results of research and observation, as well as data analysis, it can be stated that: 1 ). Through the Scientific Approach, Group Investigation (GI) in learning Hindu, XI IPS.2 Semester 1 SMA Negeri 1 Mendoyo was able to increase student learning activities and achievement, 2). Increased activity can be seen from the pre-cycle average score was $56.3 \%$, in the first cycle was $78.5 \%$ and the second cycle was $96.8 \%$. While the increase in pre-cycle group performance activities to cycle I increased by an average was $15.56 \%$ and cycle I to cycle II increased by $20.20 \%$ with an average in cycle II group performance was said to be good because it reached an average 89.25, and 3). Analysis of learning achievement that reflected from the results of student learning obtained through the results of the evaluation after the actions taken in every cycle. Improved student achievement can be seen from the number of students who completed the study was $64.71 \%$ in pre cycle, $76.47 \%$ in the first cycle and $96.06 \%$ in the second cycle. So, based on an analysis of the results mentioned above, it can be
\end{abstract}


concluded that: The efforts to increase student activity and learning achievement can be improved through a scientific approach to the GI significantly in learning Hindu.

Keywords: Scientific Approach, GI Type, Learning Activities and Achievement.

\section{Pendahuluan}

Pendidikan memegang peranan penting dalam mempersiapkan sumber daya manusia yang berkualitas dan mampu berkompetisi dalam perkembangan ilmu pengetahuan dan teknologi, sehingga pendidikan harus dilaksanakan dengan sebaikbaiknya untuk memperoleh prestasi belajar yang maksimal. Hal tersebut dapat dicapai dengan terlaksananya pendidikan yang tepat waktu dan tepat guna untuk mencapai tujuanp pembelajaran. Pembelajaran matematika di sekolah merupakan salah satu komponen pendidikan yang tidak hanya mengembangkan kemampuan dan keterampilan menerapkan matematika, melainkan mengembangkan kemampuan memecahkan masalah (Wijayanti, 2014).

Di dalam Undang-Undang No. 20 tahun 2003 tentang Sistem Pendidikan Nasional, bab 1 pasal 1 dikemukakan "Pendidikan adalah upaya sadar dan terencana untuk mewujudkan suasana belajar dan proses pembelajaran agar peserta didik secara aktif mengembangkan potensi dirinya untuk memiliki kekuatan spiritual keagamaan, pengendalian dirinya, kepribadian, kecerdasan, akhlak mulia, serta keterampilan yang diperlukan dirinya, masyarakat, bangsa dan negara." (Undang Undang Sistem Pendidikan Nasional, 2009) (Syafi'l , 2018).

Prestasi belajar diartikan sebagai ukuran pengetahuan yang didapat dari pendidikan formal dan ditunjukkan melalui nilai tes (Lawrence \& Vimala, 2012). Selaras dengan pendapat tersebut, Goods dalam Annes (2013) mendefinisikan prestasi belajar sebagai pengetahuan yang dicapai maupun keterampilan yang dikembangkan pada berbagai mata pelajaran di sekolah yang biasanya ditentukan oleh nilai ujian maupun dengan nilai yang diberikan oleh guru, atau keduanya. Kpolovie, Joe, dan Okoto (2014) menambahkan bahwa prestasi belajar merupakan kemampuan siswa untuk belajar, yakni dengan mengingat fakta dan mengkomunikasikan pengetahuannya baik secara lisan maupun tertulis, bahkan dalam kondisi ujian. Jadi, pada intinya, prestasi belajar dapat dikatakan sebagai hasil yang diperoleh dari kegiatan pembelajaran di sekolah yang bersifat kognitif dan biasanya ditentukan melalui pengukuran dan penilaian (Izzaty, 2017).

Guru memberikan peranan penting didalam pendidikan terutama didalam kegiatan belajar mengajar, agar kegiatan belajar mengajar berhasil maka guru dituntut untuk menguasai dan memahami berbagai keterampilan yang dapat mendukung efektivitas dan efesiensi kegiatan belajar mengajar. Guru adalah salah satu komponen pendidikan yang sangat berperan dalam usaha pembentukan sumber daya manusia yang potensial di bidang pembangunan. Oleh karena itu, guru merupakan salah satu unsur kependidikan harus berperan serta secara aktif dalam menempatkan kedudukannya sebagai tenaga profesional. Pada diri guru terletak tanggung jawab untuk membawa siswa pada suatu kedewasaan atau taraf kematangan tertentu. Sardiman (2012:125) mengatakan bahwa guru tidak sematamata sebagai "pengajar" yang melakukan transfer of knowledge, tetapi juga sebagai "pendidik" yang melakukan transfer of values dan "pembimbing" yang memberikan pengarahan dan menuntun siswa dalam belajar" (Firmansyah, 2015).

Rendahnya prestasi belajar yang diperoleh siswa khususnya pada mata pelajaran Agama Hindu sampai saat ini masih menjadi sorotan masyarakat. Hal ini memerlukan perhatian yang serius dari semua pihak untuk mencari faktor-faktor penyebabnya serta mencarikan solusi atau pemecahan masalah sehingga kualitas pendidikan bisa menjadi apa yang diharapkan. Siswa dikatakan tuntas apabila nilai ketuntasan klasikal mencapai 68. Rendahnya prestasi belajar siswa disebabkan oleh beberapa faktor diantaranya intelejensi siswa, motivasi belajar siswa, minat belajar, kebiasaan belajar, serta faktor luar seperti lingkungan tempat tinggal siswa, sarana 
prasarana yang mendukung proses pembelajaran yang kurang memadai. Faktor internal siswa meliputi kondisi fisiologis dan kondisi psikologis. Faktor kondisi fisiologis meliputi kesehatan jasmani dan kebugaran fisik, dan kondisi panca indra terutama penglihatan dan pendengaran, sedangkan aspek psikologis meliputi intelegensi, bakat, minat, motivasi dan kemampuan-kemampuan kognitif seperti: kemampuan persepsi, kemampuan mengingat, kemampuan berfikir, dan kemampuan awal. Faktor eksternal siswa dapat berupa: faktor keluarga, sekolah, masyarakat, dan lingkungan sosial lainnya. Hambatan dari faktor keluarga dapat berasal dari hubungan orang tua dengan anak, cara mendidik anak dari orang tua dan keteladannya, suasana rumah tangga, dan keadaan ekonomi keluarga. Hambatan dari sekolah dapat berupa cara penyajian belajar yang kurang baik, hubungan guru dengan murid, hubungan teman sebaya, bahan pelajaran, sarana dan prasarana sekolah yang tersedia, kurikulum, waktu belajar, lingkungan sekolah, disiplin sekolah. Faktor eksternal lainnya dapat berupa model pembelajaran atau strategi pembelajaran yang kurang baik (Mariawan, 2006).

Berdasarkan uraian diatas dapat disimpulkan bahwa penyebab kesulitan belajar pada diri siswa sangat kompleks. Di sisi lain, metode transfer informasi (ceramah) yang masih banyak digunakan oleh kebanyakan guru nampaknya perlu ditinggalkan, sebab siswa mempelajari pelajaran Agama Hindu dengan kepala yang kosong yang dapat diisi dengan pengetahuan Agama Hindu. Perlu adanya upaya penyempurnaan proses pembelajaran, baik itu menyangkut proses penilaian yang lebih inovatif yaitu penilaian proses dan hasil belajar yang dapat mengukur perkembangan dan kemajuan siswa secara menyeluruh yang mencakup kompetensi proses dan hasil belajar siswa maupun model pembelajaran yang mampu memfasilitasi siswa untuk mengembangkan kemampuannya berfikir secara optimal. Siswa diharapkan dapat mengetahui apa makna belajar dan bagaimana cara mencapainya. Guru sebagai fasilitator dan mediator diharapkan mampu menghilangkan perbedaan karakteristik siswa dan jurang pemisah yang terdapat pada siswa, sehingga proses pembelajaran dapat berlangsung dengan baik.

Strategi pembelajaran yang cocok untuk mengetahui perkembangan dan kemajuan siswa adalah Pendekatan Saintifik tipe group investigation (GI). Pembelajaran dengan pendekatan saintifik tipe group investigation (Gl) merupakan model pembelajaran kooperatif yang sangat kompleks dan dikembangkan pertama kali oleh Harbert Thelen (Santyasa,2004:11).

Dalam penerapannya guru membagi kelas dengan kelompok-kelompok yang berjumlah antara 2-6 orang siswa yang heterogen. Model pembelajaran kooperatif tipe group investigation (Gl) secara utuh memiliki enam langkah pembelajaran (dalam Santyasa,

2005) yaitu : (1) Grouping, (2) Planning, (3) Investigasi, (4) Organizing, (5) Presentating, dan (6) Evaluating. Pembelajaran dengan model kooperatif tipe Gl adalah pembelajaran yang berorientasi pada aktivitas kelas yang berpusat pada siswa dan memungkinkan siswa memanfaatkan berbagai sumber belajar dan tidak hanya menjadikan guru sebagai satusatunya sumber belajar. Pembelajaran dengan pendekatan saintifik tipe group investigation (GI) memungkinkan guru dapat menerapkan penilaian untuk mengetahui perkembangan aktivitas siswa, dan prestasi belajar siswa, karena dalam pembelajaran group investigation (Gl) ini, siswa yang berperan aktif dalam pembelajaran guru hanya berfungsi sebagai mediator dan fasilitator.

\section{Metode}

Penelitian dilaksanakan di SMA Negeri 1 Mendoyo dimana sekolah ini lingkungannya cukup baik dalam mendukung lancarnya pelaksanaan proses belajar mengajar karena aman, nyaman, rindang, tidak bising serta masyarakat sekitar mendukung keberadaan sekolah dengan baik. Dipilinnya Kelas XI IPS.2 Semester 1 Tahun Pelajaran 2018/2019 sebagai subjek penelitian karena penulis adalah guru yang sedang mengajar di kelas tersebut.

Untuk mencapai keberhasilan dalam pelaksanaan sebuah penelitian tindakan kelas perlu adanya rancangan. Para ahli telah membuat rancangan tersebut. Sebuah satu rancangan yang peneliti ikuti adalah rancangannya menggunakan Model Elliot,1991(dalam Sukidin, Basrowi, Suranto,2002: 52) seperti disampaikan pada gambar berikut: 
Indonesian Journal of Educational Research and Review, Vol 3 No 1, Tahun 2020 p-ISSN: 2621-4792, e-ISSN: 2621-8984

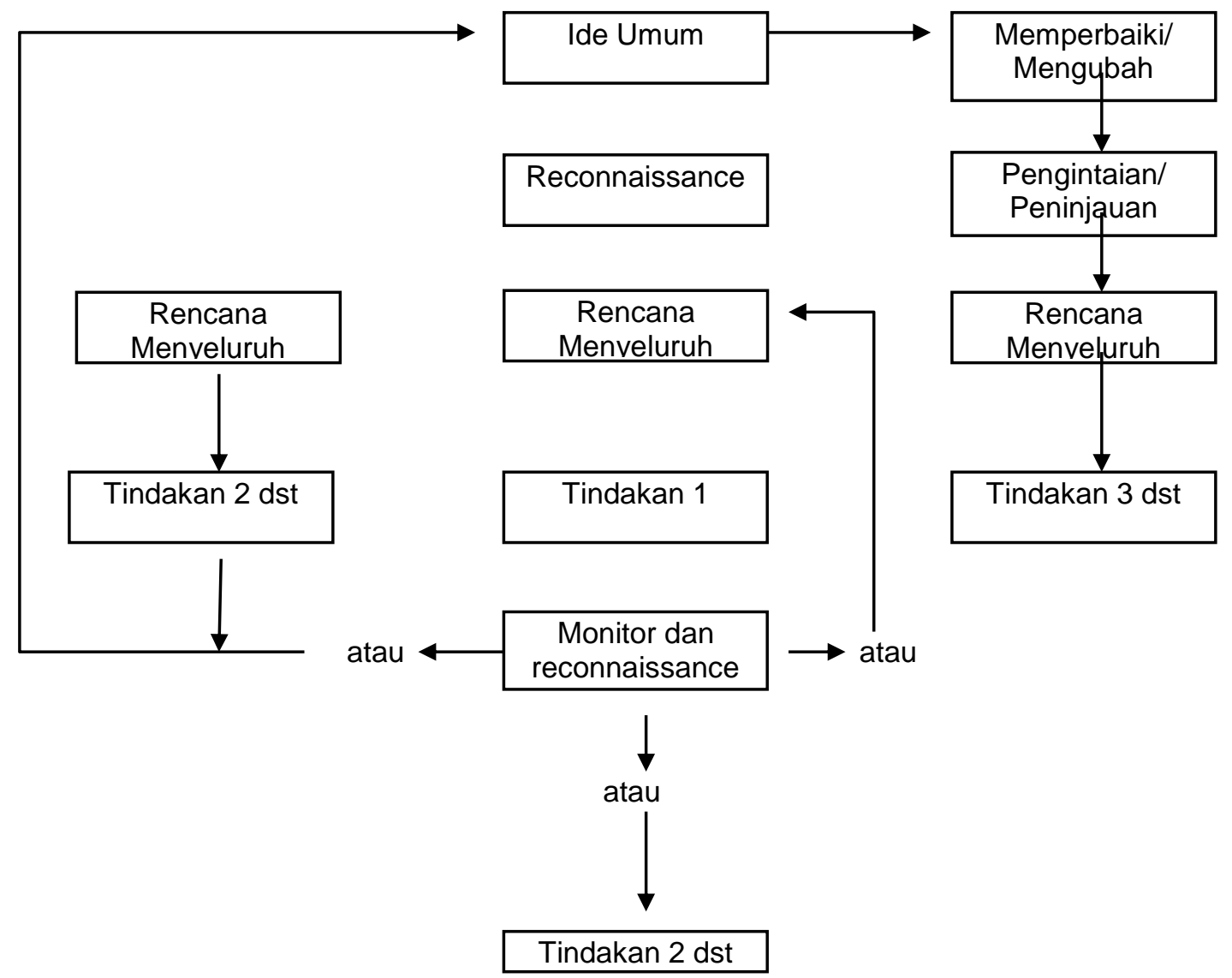

Gambar 1. Rancangan Penelitian Model Elliot (Sumber: Sukidin, Basrowi, Suranto, 2002: 52)

Prosedur merupakan langkah-langkah sesuai alur rancangan. Untuk itu prosedur yang dilakukan di kelas adalah: Mulai dari ide umum. Ide itu dicek dan bila perlu dilakukan perbaikan-perbaikan, ditinjau lagi, dibuat perecanaan menyeluruh, dilakukan tindakan, dimonitor, dicari kebenarannya, dicek yang belum, baik untuk tindakan selanjutnya.

Selanjutnya, sesudah itu dibuat lagi perencanaan untuk tindakan ke-2 berdasarkan ide umum atau masalah umum, dilakukan perbaikan/perubahan, dicek ulang atau ditinjau lagi ide-ide yang sudah didapat, dibuat perencanaan ulang secara menyeluruh, lalu dilakukan tindakan, kemudian dimonitor dan dievaluasi untuk menentukan tindakan selanjutnya.

Subjek penelitian ini adalah siswa kelas XI IPS.2 Semester 1 SMA Negeri 1 tahun pelajaran 2018/2019 dengan jumlah 34 orang siswa, dimana terdiri dari 21 orang siswa lakilaki dan 13 orang siswa perempuan. Dipilihnya siswa kelas XI IPS.2 sebagai subjek penelitian adalah karena dari hasil pengamatan awal ditemukan adanya kelemahan prestasi belajar pada siswa tersebut dan peneliti adalah guru mata pelajaran di kelas tersebut yang merasa berkewajiban memperbaiki prestasi belajar siswa melalui perbaikan model pembelajaran.

Untuk mengumpulkan data penelitian ini digunakan observasi dan tes hasil belajar sebagai cerminan dari prestasi belajar pendidikan agama hindu secara keseluruhan. Data tentang aktivitas belajar siswa selama proses pembelajaran berlangsung dengan mengunakan pedoman instrumen seperti pada Tabel berikut ini.

Tabel 1. Pedoman Instrumen observasi Aktivitas Belajar Siswa

\begin{tabular}{cll}
\hline No. & \multicolumn{1}{c}{ Aspek Aktivitas Belajar Siswa } & Prosentase(\%) \\
\hline 1 & Siswa giat memeriksa materi & \\
2 & Siswa menemukan hal-hal penting dari materi & \\
\hline
\end{tabular}


Indonesian Journal of Educational Research and Review, Vol 3 No 1, Tahun 2020

p-ISSN: 2621-4792, e-ISSN: 2621-8984

\begin{tabular}{ll}
\hline 3 & Siswa menunjukkan kemampuan analisis \\
4 & Siswa kritis dalam berpikir \\
5 & Kemampuan memecahkan masalah \\
6 & Siswa cepat menanggapi masalah \\
7 & Pembelajaran berpusat pada diri siswa \\
8 & Siswa mampu menarik berbagai kesimpulan \\
\hline
\end{tabular}

Data tentang setiap aktivitas belajar siswa dilihat dengan menggunakan format observasi aktivitas siswa, kemudian ditabulasikan, apakah aktifitasnya meningkat atau tidak. Hasil data ini dapat dinyatakan dengan baik atau kurang baik.

Kriteria klasifikasi persentase aktifitas siswa selama pembelajaran berlangsung menurut Suharsimi Arikunto (1989: 214) adalah:

Tabel 2. Pedoman Konversi Aktivitas Belajar Siswa

\begin{tabular}{ccc}
\hline No. & Interval Prosentase & Kategori \\
\hline 1 & $81-100 \%$ & Amat Baik (AB) \\
2 & $61-80 \%$ & Baik (B) \\
3 & $41-60 \%$ & Cukup (C) \\
4 & $21-40 \%$ & Kurang (K) \\
5 & $0-20 \%$ & Kurang Sekali (KS) \\
\hline
\end{tabular}

Untuk memperoleh persentase aktivitas belajar siswa, teknik analisis data yang yang digunakan adalah sesuai dengan urutan di atas diolah dengan rumus :

$$
P=(F / N) \times 100 \%
$$

Keterangan :

$\mathrm{P}=$ Angka prosentase siswa.

$\mathrm{F}=$ Frekwensi aktivitas siswa.

$\mathrm{N}=$ Jumlah siswa

Sedangkan pedoman untuk mengkonversi kinerja tiap kelompok menggunakan tabel berikut ini.

Tabel 3. Pedoman Konversi Kinerja Kelompok

\begin{tabular}{ccc}
\hline Skor & Kriteria & Nilai \\
\hline 5 & Sangat Baik & $>91$ \\
4 & Baik & $71-90$ \\
3 & Cukup baik & $51-70$ \\
2 & Kurang Baik & $31-50$ \\
1 & Tidak baik & $<30$ \\
\hline & & Sumber: Suharsimi Arikunto (1989:216)
\end{tabular}

Indikator keberhasilan penelitian tindakan ini adalah bila terjadi peningkatan aktifitas belajar dan hasil belajar siswa yang dihitung berdasarkan prosentase pada setiap siklusnya. Kriteria hasil belajar siswa menggunakan rata-rata tes ulangan harian. Sekurang-kurangnya siswa lulus secara klasikal sebanyak $68 \%$. Siswa lulus secara individual jika nilai yang diperoleh minimal 68 (sesuai kriteria ketuntasan minimal mata pelajaran Pendidikan Agama Hindu SMA Negeri 1 Mendoyo). 
Untuk keaktifan siswa dikatakan berhasil bila mencapai prosentase baik yaitu antara $61-80 \%$ dan sangat baik jika melebihi $80 \%$ siswa yang aktif. Dengan arti kata penelitian akan berhasil dan sangat baik jika ada peningkatan aktivitas belajar siswa mencapai $>80 \%$ setelah proses pembelajaran menggunakan pendekatan saintifik tipe GI.

\section{Hasil Penelitian dan Pembahasan}

Jika ditinjau dari jumlah skor dan rerata serta prosentase tingkat kenaikan pada setiap siklus dengan diterapkan pendekatan saintifik tipe GI dalam pembelajaran Pendidikan Agama hindu di kelas XI IPS.2 Semester 1 SMA Negeri 1 Mendoyo ternyata terdapat kenaikan aktivitas belajar siswa secara signifikan, pada tiap indikator aktivitas yang diamati. Untuk lebih jelasnya seperti tampak pada tabel berikut ini.

Tabel 4. Rekapitulasi Aktivitas Belajar Siswa Ditinjau Dari Jumlah Skor, Rerata, dan Prosentase Peningkatan Pada setiap Siklus.

\begin{tabular}{clcccc}
\hline No. & Kegiatan & Jumlah & Rerata & $\begin{array}{c}\text { Capaian } \\
\text { \% Peningkatan dari } \\
\text { Pra Siklus ke Siklus I }\end{array}$ & $\begin{array}{c}\text { \% Peningkatan dari } \\
\text { Siklus I ke Siklus II }\end{array}$ \\
\hline 1 & Pra Siklus & 302.94 & 37.87 & & \\
2 & Siklus I & 570.59 & 71.32 & 46.90 & 21.14 \\
3 & Siklus II & 723.53 & 90.44 & & \\
\hline
\end{tabular}

Sedangkan apabila digambarkan secara diagram batang seperti ditunjukkan pada gambar berikut ini.

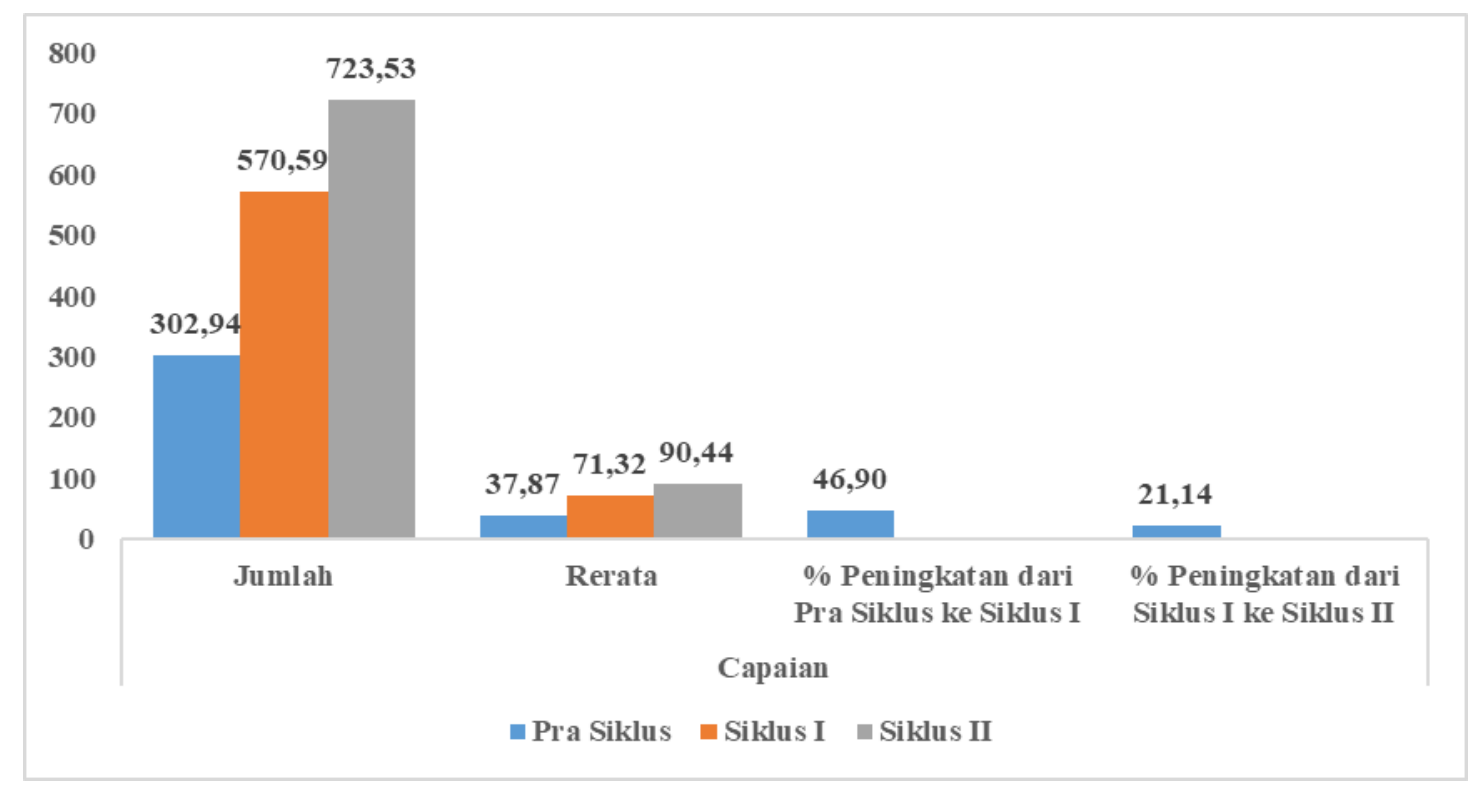

Gambar 2 Grafik Histogram Jumlah Skor,Rerata, dan Prosentase Peningkatan Aktivitas Belajar siswa Pada Setiap Siklus.

Peningkatan prestasi belajar siswa hal ini dicerminkan dari capaian hasil belajar Pendidikan Agama Hindu, siswa kelas XI IPS.2 Semester 1 SMA Negeri 1 Mendoyo. Dengan jumlah 34 orang siswa yaitu sebagai berikut: pada pra siklus jumlah siswa yang tuntas adalah 22 orang, dan 12 orang lainnya dinyatakan belum tuntas karena belum mencapai nilai 68 (sesuai dengan KKM). Sedangkan pada siklus I terdapat 26 siswa yang tuntas belajar dan 8 siswa yang belum tuntas. Pada siklus II jumlah siswa yang tuntas naik 
mencapai 33 orang dan 1 lainnya belum tuntas. Dimana tingkat kehadiran siswa saat dilaksanakan tes adalah $100 \%$.

Karena jumlah siswa yang tuntas melebihi $75 \%$, maka penelitian tindakan kelas yang dilakukan guru sudah berhasil. Artinya pendekatan saintifik tipe Gl dalam melaksanakan pembelajaran mata pelajaran Agama Hindu terbukti dapat meningkatkan hasil belajar siswa. Adapun gambar grafik kenaikan jumlah siswa yang tuntas belajar untuk tiap siklus dapat digambarkan grafik sebagai berikut:

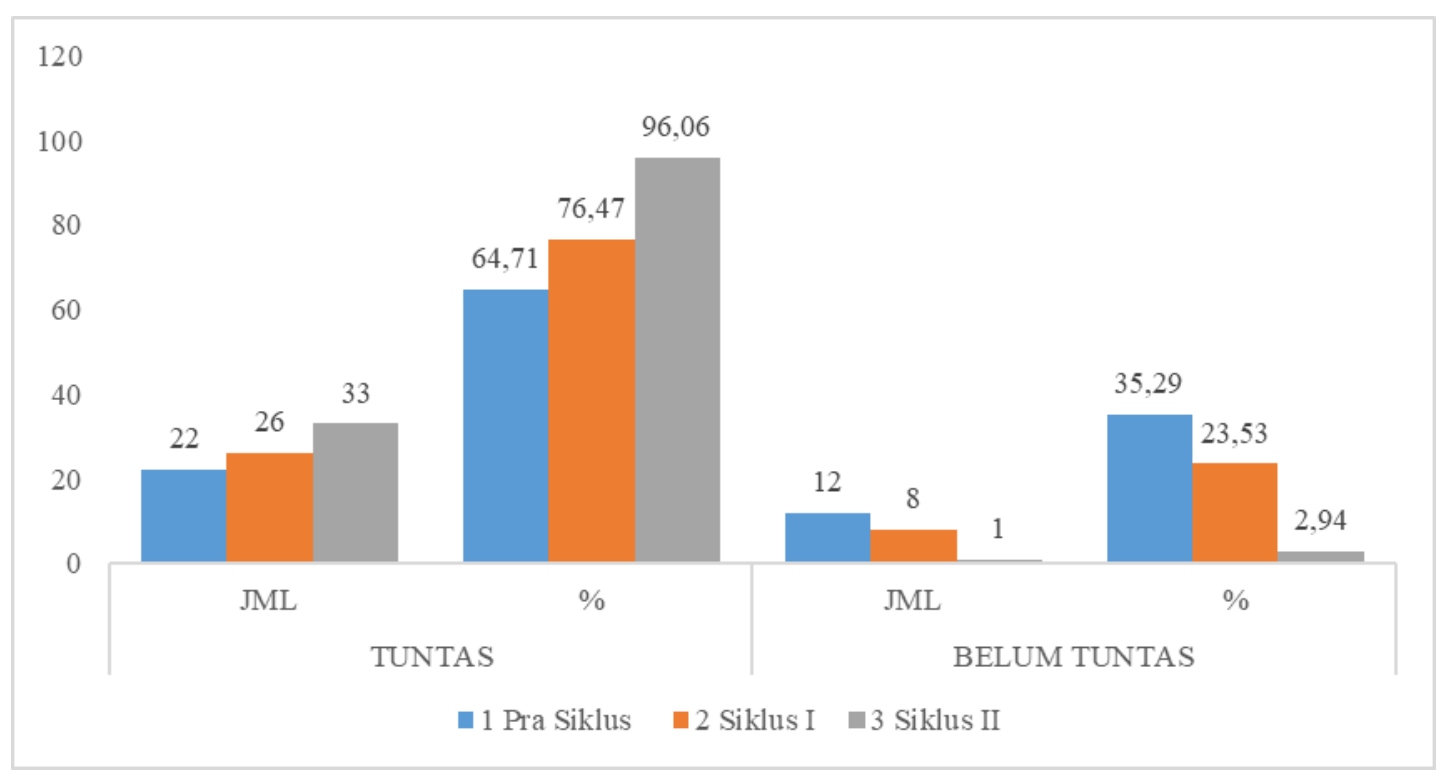

Gambar 3. Grafik Histogram Jumlah Tuntas, Belum Tuntas, dan prosentase Ketuntasan Pada Setiap Siklus

\section{Simpulan dan Saran}

Berdasarkan hasil penelitian dan obeservasi, serta analisis data yang telah diuraikan maka dapat disimpulkan bahwa:

1. Melalui Pendekatan Saintifik Tipe Group Investigation (GI) dalam pembelajaran Pendidikan Agama Hindu siswa kelas XI IPS.2 Semester 1 SMA Negeri 1 Mendoyo ternyata dapat meningkatkan aktivitas dan prestasi belajar siswa.

2. Peningkatan aktivitas dapat terlihat dari nilai rata-rata pra siklus sebesar $56,3 \%$, di siklus I sebesar $78,5 \%$ dan siklus II sebesar $96,8 \%$. Sedangkan peningkatan aktivitas kinerja kelompok pra siklus ke siklus I meningkat rata-rata $15,56 \%$ dan siklus I ke siklus II meningkat $20,20 \%$ dengan rata-rata pada siklus II kinerja kelompok sudah dikatakan baik karena mencapai rata-rata 89,25.

3. Analisis prestasi belajar yang dicerminkan dari hasil belajar siswa diperoleh melalui hasil evaluasi setelah dilaksanakan tindakan yang dilakukan setiap siklus. Peningkatan prestasi belajar siswa terlihat dari jumlah siswa yang tuntas belajar pada pra siklus $64,71 \%$, siklus I sebesar 76,47\%, dan siklus II siswa yang tuntas mencapai 96,06\%.

Berdasarkan atas beberapa simpulan diatas, maka penulis dapat memberikan beberapa saran yaitu sebagai berikut:

1. Pembelajaran pendekatan saintifik tipe GI dapat melatih siswa untuk bekerjasama mandiri maupun dalam kelompok untuk menyelidiki sesuatu kemudian mengemukakan pendapatnya melalui presentasi kelompok. Selain itu pembelajaran juga dapat meningkatkan aktivitas dan prestasi belajar hal ini dicerminkan dari hasil belajar siswa. Untuk itu diharapkan pembelajaran pendekatan saintifik tipe Gl dapat digunakan dalam proses pembelajaran pendidikan Agama Hindu. 
2. Karena ada beberapa kelemahan dari pembelajaran pendekatan saintifik tipe Gl yaitu guru harus memperhatikan pengaturan waktu dan pengontrolan siswa serta memberi penguatan dengan menjelaskan materi. Diharapkan guru dalam menerapkan pembelajaran tersebut dapat mengatur waktu seefisien mungkin dan menyiapkan bahan ajar serta meningkatkan cara penyajian misalnya dengan bantuan komputer atau media lainnya.

\section{Daftar Pustaka}

Diakses pada tgl.20 Desember 2016 pukul 12.30

Djamarah.1994. Tiori Belajar. Bandung: Rosdakarya.

Firmansyah, Dani . 2015. Pengaruh Strategi Pembelajaran Dan Minat Belajar Terhadap Hasil Belajar Matematika . Volume 3 Nomor 1, Maret 2015.

Izzaty, Rita Eka . Prediktor Prestasi Belajar Siswa Kelas 1 Sekolah Dasar . Jurnal Psikologi Volume 44, Nomor 2, 2017.

Ngainum Naim. 2009. Menjadi Guru yang Inspiratif: Memberdayakan dan Mengubah Jalan Hidup Siswa. Yogyakarta: Pustaka pelajar. http://www.eurekapendidikan.com/2015/02/model-pembelajaran-groupinvestigation.html

Slamet.2003. Faktor-Fator yang Mempengaruhi Belajar dalam Pembelajaran.Jakarta:Bumi Akasara.

Sardiman.1988. Motivasi dan Prestasi Belajar. Jakarta: Bumi Aksara.

Suharsimi, Arikunto. 1989. Dasar-dasar Evaluasi. Jakarta: Bumi Aksara.

Sukidin, Basrowi, Suranto. 2002. Menajemen Penelitian Tindakan Kelas. Penerbit: Insan Cendekia ISBN: 9799048334

Syafi'i, Ahmad. 2018. Studi Tentang Prestasi Belajar Siswa Dalam Berbagai Aspek Dan Faktor Yang Mempengaruhi . Jurnal Komunikasi Pendidikan, Vol.2 No.2, Juli 2018.

Trianto.2012. Model-Model Pembelajaran Inovatif. Jakarta: Bumi Aksara

Wijayanti, Takdir Sukmo . 2014. Meningkatkan Minat Dan Prestasi Belajar Matematika Dengan Model Pembelajaran Group Investigation Siswa Kelas Vii A Smp Negeri 1 Polanharjo Klaten . Jurnal Pendidikan Matematika Vol 2 No 1, November 2014 